\title{
Characterization of ten polymorphic microsatellite markers for an endangered butterfly Argynnis niobe and their cross-species utility in the closely related species $A$. adippe (Lepidoptera: Nymphalidae)
}

\author{
JAN ZIMA JR. ${ }^{1,2}$, DAN LEŠTINA ${ }^{1}$ and MARTIN KONVIČKA ${ }^{1,2}$ \\ ${ }^{1}$ Faculty of Sciences, Department of Zoology, Branisovska 31, 37005 Ceske Budejovice, Czech Republic; \\ e-mails: zimapanz@seznam.cz,dan.lestina@gmail.com, konva333@gmail.com \\ ${ }^{2}$ Biology Centre AS CR, Institute of Entomology, Branisovska 31, 37005 Ceske Budejovice, Czech Republic
}

Key words. Carpathian Mts, conservation genetics, Lepidoptera, Nymphalidae, Argynnis niobe, A. adippe

\begin{abstract}
The Niobe Fritillary, Argynnis niobe, is a habitat specialist and as a consequence is highly endangered in contemporary Europe. To investigate its genetic diversity and population structure, 10 polymorphic microsatellite loci were developed and characterized, using a recently developed pyrosequencing method. The number of alleles per locus ranged from 2 to 21 , and the observed and expected heterozygosities varied from 0.17 to 0.53 and from 0.24 to 0.92 , respectively. These loci were also successfully used to study the genetic diversity of a closely related species, the High Brown Fritillary, Argynnis adippe, and will be used in future population structure studies of both these species.
\end{abstract}

\section{INTRODUCTION}

Molecular markers are increasingly used in insect conservation biology as they are a cheaper and more reliable way of estimating critical population parameters important for population management, such as intra-population genetic diversity, gene flow, spatial population differentiation and effective population size (Amos \& Balmford, 2001; Palsboll et al., 2007). By using these techniques, researchers can consider scales that are much larger than the local scales of pre-molecular population ecology (Sigaard et al., 2008; Brattstrom et al., 2010) and make it possible to compare the genetic makeup over large regions (Finger et al., 2009; Habel et al., 2010), even up to continent-wide comparisons in order to unravel the colonization-extinction history within the current ranges of species (Todisco et al., 2010; Zachos \& Hartl, 2011; Runquist et al., 2012). Microsatellite markers are particularly widely used because they are codominant, hyper variable, mostly neutral and reproducible (Jarne \& Lagoda, 1996). Despite these advantages microsatellite markers have not been widely used in studies on some well studied model groups, notably butterflies and other Lepidoptera, because the sequences flanking microsatellites in this group are very similar for different loci. These similarities are generated by recombination mediated events, such as unequal crossingover or gene conversion and through transposition of mobile elements (Van't Hof et al., 2007). These problems have now been resolved thanks to next-generation sequencing methodology, which allow the rapid identification of large numbers of bioinformatically variable loci, without the necessity of laborious and costly cloning (Vandewoestijne et al., 2012).

Perhaps due to the difficulties stated above and associated high costs, population genetic studies using microsatellites have so far targeted species with only a subset of potentially diverse lepidopteran population structures. The majority of the species so far studied are sedentary, forming high-density populations in discrete patches of habitat, which are interconnected, to varying extents, by gene flow (e.g., Keyghobadi et al., 1999; Harper et al., 2000; Cassel, 2002; Zeisset et al., 2005; Sarhan, 2006; Habel et al., 2008). As a consequence of habitat loss and population isolation, such species frequently suffer declines of withinpopulation genetic diversity caused by inbreeding and/or genetic drift (Habel et al., 2011), making it important in the context of the conservation of these species to consider their population genetic structure. The population structures of these mainly sedentary species, however, were rather well rendered by premolecular approaches, such as mark-recapture, and the molecular genetics results often tended to elaborate what was already expected. There are studies on species at the opposite extreme of possible butterfly population structures, i.e. migratory species that occur as panmictic populations spread over huge geographic distances (Vandewoestijne \& Van Dyck, 2010), but such species are seldom of concern to conservationists because they easily replace population losses through immigration.

Species with intermediate dispersal ability fall between these two extremes and have been studied much less, although their fates in modern landscapes should be of great concern to conservationists. More than a decade ago, Thomas (2000) observed that in Western Europe butterflies of intermediate mobility were declining more than their sedentary and mobile counterparts and rapid declines were subsequently reported for several intermediately mobile species (e.g., Konvicka et al., 2008; Kadlec et al., 2010). This is due to the inverse relationship between dispersal and population density (Cowley et al., 2001a, b; Konvicka et al., 2012), which predicts that species that are too mobile to be restricted to patches of a few hectares (cf. Ehrlich \& Hanski, 2004), but not as mobile as true migrants (cf. Vandewoestijne et al., 1999), will require relatively large areas of habitat in order to sustain viable populations. As many European species depend on habitats maintained for centuries by preindustrial land use patterns (Settele et al., 2009), conserving such species requires maintaining or mimicking traditional land use over scales that are too large for a single-site approach. A better understanding of the genetic makeup of populations of intermediately mobile species' is a necessary first step in delimiting the boundaries of conservation management units from the point of view of the species concerned. Until now, very few of the species that are declining in abundance and have an intermediate gene flow 
have been subjected to genetic analyses, a notable exception being the North American fritillary Speyeria idalia (Drury, 1773) (Williams et al., 2003).

We developed microsatellite markers for two intermediately mobile, low-density species of high conservation concern in Europe, the Niobe Fritillary Argynnis niobe (Linnaeus, 1758) and High Brown Fritillary Argynnis adippe (Denis \& Schiffermüller, 1775) (Nymphalidae: Heliconinae). These two closely related species belong to the subgenus Fabriciana of the genus Argynnis (Simonsen, 2006; Simonsen et al., 2006) and both have broad ranges in the Palaearctic, were historically widespread across Central Europe and inhabit a diverse range of landscapes with grassland, pastures, orchards and woodlots (Tolman \& Levington, 1997; Kudrna et al., 2011). As a likely result of land use changes, they became less widespread in many countries and retreated to remote regions that still practice small-scale farming (cf. Spitzer et al., 2009), thus indicating their dependency on large areas consisting of a mosaic of habitats as existed before the intensification of agriculture. Examples of such regions include the offshore islands of Germany (Salz \& Fartmann, 2009) and Estonia (Sang et al., 2010) or mountainous regions (Spitzer et al., 2009b; Verovnik et al., 2012). The declines in the abundance of $A$. adippe are less severe and of little concern on a continental basis (Van Swaay et al., 2010), but this species is severely threatened in Britain, for example (Fox et al., 2011). The situation appears much worse for $A$. niobe, which has disappeared from most of Germany (Salz \& Fartmann, 2009), and is now near-threatened continentally (Van Swaay et al., 2010). In the Czech Republic, where the material for this study was collected, the extent of the distribution of $A$. adippe was at its lowest a decade ago and is now recovering, whereas the current distribution of $A$. niobe is 40 per-cent of what it was in the 1950s and this species is now critically endangered (Benes et al., 2002).

\section{MATERIAL AND METHODS}

Samples were collected during summer 2011 in the Vsetínská Bečva valley, a sub-mountainous area extending for approximately $200 \mathrm{~km}^{2}$ (centroid coordinates: $49^{\circ} 19^{\prime} \mathrm{N}, 18^{\circ} 9^{\prime} \mathrm{E}$ ) close to the Czech-Slovakian border, which is still traditionally farmed and where both species reach their highest densities within the Czech Republic.

Genomic DNA was extracted from a little piece of wing using the DNeasy Blood\&Tissue kit (QIAGEN), which is a way of obtaining tissue samples from butterflies without damaging them (Hamm et al., 2010) and especially important in the case of endangered species. Initially, we reviewed the literature for microsatellites already developed for related species in order to try cross-species amplification. The only existing primers potentially suitable for cross-species amplification were those designed by Williams et al. (2002) for a related fritillary, Speyeria idalia. Forward primers were fluorescently labelled and PCR products were analyzed using fragment analysis on an automated sequencer. A variety of PCR conditions were tested, but none of the primer pairs provided microsatellite PCR products.

For the next step, primers were developed de novo using the recent and highly efficient pyrosequencing method (Ronaghi, 2001). DNA from four Argynnis niobe individuals was pooled and sent to GenoScreen (France) for the GenoSat service, combining DNA enrichment procedures with the use of multiplexed microsatellite probes and the update Titanium of the 454 GS-FLX technology (Malausa et al., 2011) (see Vandewoestijne et al., 2012 for more details). Obtained primers were analyzed for all primer secondary structures including hairpins, selfdimers and cross-dimers in primer pairs, using the on-line appli- cation NetPrimer, available at http://www.premierbiosoft.com/ netprimer/.

These secondary structures should be avoided if possible, because they could reduce amplification success. Primers were also checked for the presence of $\mathrm{G}$ or $\mathrm{C}$ bases within the last five bases from the $3^{\prime}$ end of primers (GC clamp), which helps to promote specific binding at the $3^{\prime}$ end due to the stronger bonding of $\mathrm{G}$ and $\mathrm{C}$ bases. In general, we followed the PCR primer design guidelines reviewed at http://www. premierbiosoft.com/tech_notes/PCR_Primer_Design.html.

Initially, we tried PCR amplification with unlabelled primers, followed by $1 \%$ agarose gel electrophoresis, on eight individuals (four $A$. addipe and four $A$. niobe), to determine which primer pairs provided suitable PCR products. Subsequently, we ordered fluorescently labelled primers (only forward: 6-FAM, NED, PET, or VIC, Applied Biosystems). We performed monoplex PCR on the same eight individuals for each of the fluorescently labelled primers using Combi PPP-MasterMix (Top-Bio). The total reaction volume was $12 \mu \mathrm{l}$, containing $4 \mu \mathrm{l}$ of MasterMix, $1 \mu 1$ of each primer (final $c=0.08 \mathrm{nmol}$ ), $4 \mu$ of PCR $\mathrm{H}_{2} \mathrm{O}$ and $20 \mathrm{ng}$ of DNA. Cycling parameters were: $4 \mathrm{~min}$ of initial denaturation at $94^{\circ} \mathrm{C}$, followed by 35 cycles of $94^{\circ} \mathrm{C}(30 \mathrm{~s})$, $54^{\circ} \mathrm{C}(60 \mathrm{~s}), 72^{\circ} \mathrm{C}(60 \mathrm{~s})$, with final elongation at $72^{\circ} \mathrm{C}$ for 5 min. We also tested different annealing temperatures $\left(50^{\circ}, 52^{\circ}\right.$, $56^{\circ}, 58^{\circ}$ ), but $54^{\circ} \mathrm{C}$ provided the best results. The PCR products were then analysed by fragment analysis on automated sequencer ABI 3130 and allelic patterns were scored with software GeneMapper (Applied Biosystems) to determine which loci were polymorphic and can be reliably scored.

For the selected loci, we genotyped another 24 individuals of each species and thus had a total of 32 genotyped individuals per species (24 males and 8 females). Basic parameters of loci, such as number of alleles $(\mathrm{Na})$, observed $\left(H_{o}\right)$ and expected $\left(H_{e}\right)$ heterozygosities, were calculated using the software GenAlEx (Peakall \& Smouse, 2006). All loci in both species were also tested for Hardy-Weinberg equilibrium (HWE). The occurrence of null alleles was tested using the software FreeNA (Chapuis \& Estoup, 2007) and linkage disequilibrium tests were computed in Genepop 4.0 (Rousset, 2008). Because butterflies have heterogametic females and there is always the possibility that genetic markers are sex-linked, we checked for at least one heterozygotic female genotype at every locus.

\section{RESULTS}

From the GenoSat service we obtained 67671 sequences, of which 8144 contained microsatellite motifs and the software analysis (provided by GenoScreen) resulted in 388 bioinformatically validated pairs of primers. Based on the NetPrimer analyses, we selected the thirty most suitable primer pairs. Out of these thirty primer pairs, eighteen provided consistent products of between 100 and $300 \mathrm{bp}$. Of these eighteen loci, analysed with fluorescent labels on the forward primer, two were monomorphic, six exhibited an unclear pattern with unspecific products indistinguishable from real alleles, and ten were polymorphic with reliably scorable alleles.

The basic parameters of the ten loci selected, based on 32 genotyped individuals of each species, are given in Table 1 . The mean number of alleles per locus was 8.2 for $A$. niobe and 4.8 for $A$. adippe. The average observed proportion of heterozygotes over all loci $\left(H_{o}\right)$ was 0.33 in $A$. niobe and 0.30 in $A$. adippe, while the level of expected heterozygosity $\left(H_{e}\right)$ reached 0.62 in the former and 0.44 in the latter species. Seven loci in $A$. niobe and four in $A$. adippe were not in HWE. These loci exhibited null alleles with frequencies $0.09-0.34$. The exact test for linkage disequilibrium resulted in non-significant $P$-values, allowing us to consider the analysed loci independent. We found 
TABLE 1. Characterization of 10 polymorphic microsatellite loci in Argynnis niobe and A. adippe. Locus name, forward (F) and reverse (R) primer sequences, repeat motif, size range of alleles, number of alleles $(\mathrm{Na})$, observed $\left(H_{o}\right)$ and expected $\left(H_{e}\right)$ heterozygosities, and statistical significance of the HWE test ( $\mathrm{ns}=$ not significant, $* * * \mathrm{P}<0.001)$ for 32 individuals of each species.

\begin{tabular}{|c|c|c|c|c|c|c|c|c|c|c|c|c|}
\hline \multirow{2}{*}{$\begin{array}{l}\text { Locus } \\
\text { name }\end{array}$} & \multirow{2}{*}{ Primer sequences $\left(5 \rightarrow 3^{\prime}\right)$} & \multirow{2}{*}{ Motif } & \multicolumn{5}{|c|}{ A. niobe } & \multicolumn{5}{|c|}{ A. adippe } \\
\hline & & & Range & $\mathrm{Na}$ & Ho & $\mathrm{He}$ & HWE & Range & $\mathrm{Na}$ & Ho & $\mathrm{He}$ & HWE \\
\hline \multirow[t]{2}{*}{ An_5 } & F:CGATTGCATATACATCGTGC & CTAT & $118-148$ & 11 & 0.25 & 0.80 & $* * *$ & $118-140$ & 3 & 0.00 & 0.23 & $* * *$ \\
\hline & R:CCTGTTCAAAAGATTCCGTCA & & & & & & & & & & & \\
\hline \multirow[t]{2}{*}{ An_20 } & F:TAGATCCAGTGGTCGCCTTT & TGTA & $186-428$ & 21 & 0.33 & 0.92 & $* * *$ & $186-206$ & 4 & 0.50 & 0.54 & ns \\
\hline & R:ATATGACAGTCGGGAGACGG & & & & & & & & & & & \\
\hline \multirow[t]{2}{*}{ An_21 } & F:CATCGTGACGAAATCTGCAT & ATAC & $213-228$ & 8 & 0.28 & 0.68 & $* * *$ & $213-229$ & 4 & 0.10 & 0.62 & $* * *$ \\
\hline & R:AGGCTACATTTTGCCCTGTG & & & & & & & & & & & \\
\hline \multirow[t]{2}{*}{ An_22 } & F:TCCGTTCGCTACCAAACTTC & TA & $168-254$ & 14 & 0.27 & 0.82 & $* * *$ & $176-226$ & 11 & 0.28 & 0.64 & $* * *$ \\
\hline & R:AGTTATCATCGCTTCGCTCG & & & & & & & & & & & \\
\hline \multirow[t]{2}{*}{ An_24 } & F:GTGCAGGGAAGGAAGAGAAG & AG & $74-122$ & 7 & 0.53 & 0.66 & $* * *$ & $100-106$ & 4 & 0.19 & 0.60 & $* * *$ \\
\hline & R:ATGAATGGAGTTTCGCCAAG & & & & & & & & & & & \\
\hline \multirow[t]{2}{*}{ An_25 } & F:TTAAAAGAGCTTGCTGCGGT & TG & $186-194$ & 4 & 0.50 & 0.57 & $\mathrm{~ns}$ & $188-200$ & 4 & 0.40 & 0.35 & ns \\
\hline & R:TGCATCAAATGTGTTACGTGC & & & & & & & & & & & \\
\hline \multirow[t]{2}{*}{ An_26 } & F:TGTCGAATCAAGAAATTAGAATGC & ATCT & $86-102$ & 5 & 0.22 & 0.30 & $* * *$ & 90 & 1 & 0.00 & 0.00 & - \\
\hline & R:CAAGAATTGCTCGTTTAAAAGTATT & & & & & & & & & & & \\
\hline \multirow[t]{2}{*}{ An_27 } & F:ACCAAGTTCCACCCATCTGA & CTT & $175-181$ & 2 & 0.28 & 0.24 & $\mathrm{~ns}$ & $175-190$ & 5 & 0.44 & 0.36 & $\mathrm{~ns}$ \\
\hline & R:CACAGAAGCCACTGCCACTA & & & & & & & & & & & \\
\hline \multirow[t]{2}{*}{ An $\_28$} & F:TTACAACATGATTACCATTAGCCA & GT & $126-146$ & 6 & 0.17 & 0.75 & $* * *$ & $134-148$ & 8 & 0.84 & 0.83 & $\mathrm{~ns}$ \\
\hline & R:GGTACGAACCTTCTACCTGGTC & & & & & & & & & & & \\
\hline \multirow[t]{2}{*}{ An_30 } & F:GCCATTATTGTATCCTCCTTGG & TTG & $240-249$ & 4 & 0.50 & 0.43 & ns & $237-246$ & 4 & 0.25 & 0.23 & ns \\
\hline & R:CGTCAAAAGAGCAATCAGTGG & & & & & & & & & & & \\
\hline
\end{tabular}

at least one heterozygotic female at each of the loci, indicating that none of the loci were sex-linked (i.e. localised on the W-chromosome).

\section{DISCUSSION AND CONCLUSIONS}

The development of microsatellite markers using the pyrosequencing method has greatly facilitated their use in molecular ecology by reducing the cost and the time required to analyze samples (Santana et al., 2009). Now almost anyone can easily access a useful tool for investigating natural populations of nonmodel organisms. In this report, we describe ten polymorphic microsatellites for two closely related butterfly species of high conservation importance. We see this paper as a pilot study, taking advantage of only a small part of the raw data set, the rest of which can be used to isolate more microsatellite loci in the future. However, the population genetic parameters based on our ten loci are already informative and non-trivial, hinting at the occurrence of interesting evolutionary phenomena within the populations studied.

Primers were designed for Argynnis niobe, but the testing of polymorphism was performed for both species simultaneously, which led to relatively high cross-species amplification success, which is uncommon in Lepidoptera. Although some loci exhibited null alleles, the homozygote excess was more likely caused by the strong prevalence of only one type of allele at most loci. We did not detect any locus for which some individuals would fail to amplify at least one allele, which suggests that the homozygote excess was not due to null alleles, but represented genuine homozygosity (Dakin \& Avise, 2004). Homozygote excess is usually interpreted as evidence for inbreeding and/or genetic drift (Frankham et al., 2008), but this needs to be confirmed by an analysis of more individuals.

In Table 2, we provide a brief comparison of the microsatellite loci parameters obtained in several other studies on Lepi-

TABLE 2. Comparison of microsatellite loci parameters obtained in other studies on Lepidoptera that used similar sized samples. Mean number of alleles per locus $(\mathrm{Na})$, expected $\left(H_{e}\right)$ and observed $\left(H_{o}\right)$ heterozygosities.

\begin{tabular}{llcccc}
\hline Source study & Species & Sample size & Number of loci & Na & $H_{e} / H_{o}$ \\
\hline Vila et al., 2009 & Erebia palarica & 35 & 10 & 14.3 & $0.82 / 0.75$ \\
Petenian et al., 2005 & Parnassius apollo & 40 & 6 & 7.5 & $0.45 / 0.33$ \\
Petenian et al., 2005 & Euphydryas aurinia & 40 & 5 & 14 & $0.86 / 0.42$ \\
Rousselet et al., 2004 & Thaumetopoea pityocampa & 30 & 5 & 6.6 & $0.70 / 0.62$ \\
This study & Argynnis adippe & 32 & 10 & 4.8 & $0.44 / 0.30$ \\
This study & Argynnis niobe & 32 & 10 & 8.2 & $0.62 / 0.33$ \\
\hline
\end{tabular}


doptera that used similar sized samples. Genetic variability, expressed in terms of the number of alleles per locus and observed heterozygosity, was very low in our focal species, which indicates a strong influence of genetic drift and inbreeding on their population genetic structures. Surprisingly, the number of alleles per locus was two times lower in the locally more abundant and less threatened $A$. adippe. The longterm dataset (Benes et al., 2002; and Czech Butterfly Recording) available for this species suggests that this could have been caused by a bottleneck event that happened several decades ago, when there was a more drastic decline in numbers in $A$. adippe than $A$. niobe, but for a more accurate interpretation a more robust dataset is needed.

ACKNOWLEDGEMENTS. We would like to thank P. Butterill for language revision and two anonymous reviewers for their helpful comments. This study was supported by the Czech Science Foundation (P505/10/2167) and University of South Bohemia (04-144/2010/P).

\section{REFERENCES}

Amos W. \& BaLmford A. 2011: When does conservation genetics matter? - Heredity 87: 257-265.

Benes J., Konvicka M., Dvorak J., Fric Z., Havelda Z., Pavlicko A., Vrabec V. \& Weidenhoffer Z. 2002: Butterflies of the Czech Republic: Distribution and Conservation I. SOM, Prague, $478 \mathrm{pp}$.

Brattstrom O., Akesson S. \& Bensch S. 2010: AFLP reveals cryptic population structure in migratory European red admirals (Vanessa atalanta). - Ecol. Entomol. 35: 248-252.

CASSEL A. 2002: Characterization of microsatellite loci in Coenonympha hero (Lepidoptera: Nymphalidae). - Mol. Ecol. Notes 2: 566-568.

Chapuis M.P. \& Estoup A. 2007: Microsatellite null alleles and estimation of population differentiation. - Mol. Biol. Evol. 24: 621-631.

Cowley M.J.R., Thomas C.D., Roy D.B., WiLson R.J., Leon-Cortes J.L., Gutierrez D., Bulman C.R., Quinn R.M., Moss D. \& GASTON K.J. 2001a: Density-distribution relationships in British butterflies. I. The effect of mobility and spatial scale. - J. Anim. Ecol. 70: 410-425.

Cowley M.J.R., Thomas C.D., Wilson R.J., Leon-Cortes J.L., Gutierrez D. \& Bulman C.R. 2001b: Density-distribution relationships in British butterflies. II. An assessment of mechanisms. - J. Anim. Ecol. 70: 426-441.

DAKIN E.E. \& Avise J.C. 2004: Microsatellite null alleles in parentage analysis. - Heredity 93: 504-509.

EhrLich P.R. \& HANSKI I. 2004: On the Wings of Checkerspots: A Model System for Population Biology. Oxford University Press, New York, 371 pp.

Finger A., Schmitt T., Zachos F.E., Meyer M., Assmann T. \& Habel J.C. 2009: The genetic status of the violet copper Lycaena helle - a relict of the cold past in times of global warming. Ecography 32: 382-390.

Fox R., Warren M.S., Brereton T.M., Roy D.B. \& Robinson A. 2011: A new Red List of British butterflies. Insect Conserv. Divers. 4: 159-172.

Frankham R., Ballou J. \& Briscoe D. 2008: Introduction to Conservation Genetics. Cambridge University Press, Cambridge, $617 \mathrm{pp}$.

Habel J.C., Finger A., Meyer M., Schmitt T. \& Assmann T. 2008: Polymorphic microsatellite loci in the endangered butterfly Lycaena helle (Lepidoptera: Lycaenidae). Eur. J. Entomol. 105: 361-362.

Habel J.C., Schmitt T., Meyer M., Finger A., Rodder D., AssMANN T. \& ZACHOS F.E. 2010: Biogeography meets conserva- tion: the genetic structure of the endangered lycaenid butterfly Lycaena helle (Denis \& Schiffermuller, 1775). — Biol. J. Linn. Soc. Lond. 101: 155-168.

Habel J.C., Finger A., Schmitt T. \& Neve G. 2011: Survival of the endangered butterfly Lycaena helle in a fragmented environment: Genetic analyses over 15 years. - J. Zool. Syst. Evol. Res. 49: 25-31.

Hamm C.A., Aggarwal D. \& Landis D.A. 2010: Evaluating the impact of non-lethal DNA sampling on two butterflies, Vanessa cardui and Satyrodes eurydice. - J. Insect Conserv. 14: 11-18.

Harper G.L., Piyapattanakorn S., Goulson D. \& Maclean N. 2000: Isolation of microsatellite markers from the Adonis blue butterfly (Lysandra bellargus). - Mol. Ecol. 9: 1948-1949.

Jarne P. \& LAGODA P.J.L. 1996: Microsatellites, from molecules to populations and back. - Trends Ecol. Evol. 11: 424-429.

Kadlec T., Vrba P., Kepka P., Schmitt T. \& Konvicka M. 2009: Tracking the decline of the once-common butterfly: delayed oviposition, demography and population genetics in the hermit Chazara briseis. - Anim. Conserv. 13: 172-183.

Keyghobadi N., Roland J. \& Strobeck C. 1999: Influence of landscape on the population genetic structure of the alpine butterfly Parnassius smintheus (Papilionidae). - Mol. Ecol. 8: $1481-1495$.

Konvicka M., Benes J., Cizek O., Kopecek F., Konvicka O. \& VITAZ L. 2008: How too much care kills species: Grassland reserves, agri-environmental schemes and extinction of Colias myrmidone (Lepidoptera: Pieridae) from its former stronghold. - J. Insect Conserv. 12: 519-525.

Konvicka M., Zimmermann K., Klimova M., Hula V. \& Fric Z. 2012: Inverse link between density and dispersal distance in butterflies: field evidence from six co-occurring species. Popul. Ecol. 54: 91-101.

Kudrna O., Harpke A., Lux K., Pennerstorfer J., Schweiger O., Settele J. \& Wiemers M. 2011: Distribution Atlas of Butterflies in Europe. Geselschaft für Schmetterlingsschutz e.V., Halle, 576 pp.

Malausa T., Gilles A., Megleccz E. et Al. 2011: Highthroughput microsatellite isolation through 454 GS-FLX Titanium pyrosequencing of enriched DNA libraries. - Mol. Ecol. Resour. 11: 638-644.

Palsboll P.J., Berube M. \& Allendorf F.W. 2007: Identification of management units using population genetic data. Trends Ecol. Evol. 22: 11-16.

Peakall R. \& Smouse P. 2006: GenaleX 6: Genetic analysis in Excel. Population genetic software for teaching and research. - Mol. Ecol. Notes 6: 288-295.

Petenian F., Meglécz E., Genson G., Rasplus J. \& Faure E. 2005: Isolation and characterization of polymorphic microsatellites in Parnassius apollo and Euphydryas aurinia (Lepidoptera). - Mol. Ecol. Notes 5: 243-245.

RonAGHI M. 2001: Pyrosequencing sheds light on DNA sequencing. - Genome Res. 11: 3-11.

Rousselet J., Magnoux E. \& Kerdelhué C. 2004: Characterization of five microsatellite loci in the Pine Processionary Moth Thaumetopoea pityocampa (Lepidoptera: Notodontidae: Thaumetopoeinae). - Mol. Ecol. Notes 4: 213-214.

RouSSET F. 2008: GENEPOP'007: a complete re-implementation of the GENEPOP software for Windows and Linux. Mol. Ecol. Resour. 8: 103-106.

Runquist E.B., Forister M.L. \& Shapiro A.M. 2012: Phylogeography at large spatial scales: incongruent patterns of population structure and demography of Pan-American butterflies associated with weedy habitats. $-J$. Biogeogr. 39: 382-396. 
SAlz A. \& Fartmann T. 2009: Coastal dunes as important strongholds for the survival of the rare Niobe fritillary (Argynnis niobe). - J. Insect Conserv. 13: 643-654.

Sang A., Teder T., Helm A. \& Partel M. 2010: Indirect evidence for an extinction debt of grassland butterflies half century after habitat loss. - Biol. Conserv. 143: 1405-1413.

Santana Q.C., Coetzee M.P.A., Steenkamp E.T. et Al. 2009: Microsatellite discovery by deep sequencing of enriched genomic libraries. - Bio Techniques 46: 217-223.

SARHAN A. 2006: Isolation and characterization of five microsatellite loci in the Glanville fritillary butterfly (Melitaea cinxia). - Mol. Ecol. Notes 6: 163-164.

Settele J., Shreeve T., Konvicka M. \& Van Dyck H. 2009: Ecology of Butterflies in Europe. Cambridge University Press, Cambridge, $513 \mathrm{pp}$.

Sigaard P., Pertoldi C., Madsen A.B., SogaArd B. \& LOESCHCKe V. 2008: Patterns of genetic variation in isolated Danish populations of the endangered butterfly Euphydryas aurinia. - Biol. J. Linn. Soc. Lond. 95: 677-687.

SiMONSEN T.J. 2006: Fritillary phylogeny, classification, and larval host plants: reconstructed mainly on the basis of male and female genitalic morphology (Lepidoptera: Nymphalidae: Argynnini). — Biol. J. Linn. Soc. Lond. 89: 627-673.

Simonsen T.J., Wahlberg N., Brower A.V.Z. \& DE Jong R. 2006: Morphology, molecules and fritillaries: approaching a stable phylogeny for Argynnini (Lepidoptera: Nymphalidae). - Insect Syst. Evol. 37: 405-418.

Sitzzer L., Benes J., Dandova J., Jaskova V. \& Konvicka M. 2009a: The Large Blue butterfly, Phengaris [Maculinea] arion, as a conservation umbrella on a landscape scale: The case of the Czech Carpathians. - Ecol. Indic. 9: 1056-1063.

Spitzer L., Beneš J. \& KonvičKa M. 2009b: Oviposition of the Niobe fritillary [Argynnis niobe (Linnaeus, 1758)] at submountain conditions in the Czech Carpathians (Lepidoptera, Nymphalidae). - Nachr. Entomol. Ver. Apollo 30: 165-168.

Thомаs C.D. 2000: Dispersal and extinction in fragmented landscapes. - Proc. R. Soc. Lond. (B) 267: 139-145.

Todisco V., Gratton P., Cesaroni D. \& Sbordoni V. 2010: Phylogeography of Parnassius apollo: hints on taxonomy and conservation of a vulnerable glacial butterfly invader. - Biol. J. Linn. Soc. Lond. 101: 169-183.

Tolman T. \& Levington R. 1997: Butterflies of Britain and Europe. Harper Collins, London, 320 pp.

Vandewoestijne S. \& Van Dyck H. 2010: Population genetic differences along a latitudinal cline between original and recently colonized habitat in a butterfly. - Plos One 5: 11, Article Number: e13810

Vandewoestijne S., Néve G. \& Baguette M. 1999: Spatial and temporal population genetic structure of the butterfly Aglais urticae L. (Lepidoptera, Nymphalidae). - Mol. Ecol. 8: $1539-1543$.

Vandewoestijne S., Turlure C. \& Baguette M. 2012: Development of novel microsatellite markers for a specialist species of Lepidoptera, Boloria aquilonaris (Nymphalidae), based on 454 sequences. - Eur. J. Entomol. 109: 129-134.

Van Swaay C., Cuttelod A., Collins S. et al. 2010: European Red List of Butterflies. Publications Office of the European Union, Luxembourg, 48 pp.

Van't Hof A.E., Brakefield P.M., SACcheri I.J. \& ZwaAn B.J. 2007: Evolutionary dynamics of multilocus microsatellite arrangements in the genome of the butterfly Bicyclus anynana, with implications for other Lepidoptera. Heredity 98: 320-328.

Verovnik R., RebeušEK F. \& Jež M. 2012: Atlas of Butterflies (Lepidoptera: Rhopalocera) of Slovenia. Centre for Cartography of Fauna and Flora, Miklaž na Dravskem Polju, 456 pp

Vila M., Latasa T., Pino J.J. \& Verhulst G. 2009: Characterization of ten polymorphic microsatellite markers for the endemic Chapman's ringlet, Erebia palarica (Lepidoptera: Nymphalidae). - Eur. J. Entomol. 106: 485-490.

WARREN M.S. 1995: Managing local microclimates for the High Brown fritillary, Argynnis adippe. In Pullin A.S. (ed.): Ecology and Conservation of Butterflies. Chapman \& Hall, London, pp. 198-210.

Williams B.L., Brawn J.D. \& Paige K.N. 2002: Highly polymorphic microsatellite loci for Speyeria idalia (Lepidoptera: Nymphalidae). - Mol. Ecol. Notes 2: 87-88.

Williams B.L., Brawn J.D. \& Paige K.N. 2003: Landscape scale genetic effects of habitat fragmentation on a high gene flow species: Speyeria idalia (Nymphalidae). - Mol. Ecol. 12: $11-20$.

ZAChOS F.E. \& Hartl G.B. 2011: Phylogeography, population genetics and conservation of the European red deer Cervus elaphus. - Mamm. Rev. 41: 138-150.

Zeisset I., Als T.D., Settele J. \& Boomsma J.J. 2005: Microsatellite markers for the large blue butterflies Maculinea nausithous and Maculinea alcon (Lepidoptera: Lycaenidae) and their amplification in other Maculinea species. - Mol. Ecol. Notes 5: 165-168.

Received August 31, 2012; revised and accepted November 21, 2012 